\title{
Isolation and structure elucidation of a novel androgen antagonist, arabilin, produced by Streptomyces sp. MK756-CF1
}

\author{
Tatsuro Kawamura ${ }^{1,3}$, Takahiro Fujimaki ${ }^{1,3}$, Natsuki Hamanaka ${ }^{1}$, Kentaro Torii ${ }^{1}$, Hiroki Kobayashi ${ }^{1}$, \\ Yoshikazu Takahashi ${ }^{2}$, Masayuki Igarashi ${ }^{2}$, Naoko Kinoshita ${ }^{2}$, Yoshio Nishimura ${ }^{2}$, Etsu Tashiro ${ }^{1}$ \\ and Masaya Imoto ${ }^{1}$
}

In the course of screening for a new type of androgen receptor (AR) antagonist, we isolated a novel compound, arabilin, with two structural isomers, spectinabilin and SNF4435C, produced by Streptomyces sp. MK756-CF1. Structure elucidation on the basis of the spectroscopic properties showed that arabilin is a novel polypropionate-derived metabolite with a $p$-nitrophenyl group and a substituted $\gamma$-pyrone ring. Arabilin competitively blocked the binding of androgen to the ligand-binding domain of AR in vitro. In addition, arabilin inhibited androgen-induced prostate-specific antigen mRNA expression in prostate cancer LNCaP cells. The Journal of Antibiotics (2010) 63, 601-605; doi:10.1038/ja.2010.98; published online 25 August 2010

Keywords: androgen antagonist; prostate cancer; PSA

\section{INTRODUCTION}

Androgen receptor (AR), a member of the nuclear receptor superfamily, is a critical mediator of prostate cancer; therefore, treatment with AR antagonists is expected to be an effective prostate cancer therapy. AR antagonists can be classified into two structural types, steroidal and nonsteroidal compounds. ${ }^{1,2}$ Steroidal AR antagonists often exhibit side effects because of cross-reactivity with other steroid hormone nuclear receptors, such as estrogen receptor and progesterone receptor. On the other hand, anilide-type compounds, such as flutamide and bicalutamide, are representative of nonsteroidal AR antagonists. Although these anilide-type AR antagonists have been clinically used for prostate cancer therapy, prostate cancer often advances to a hormone-refractory state after long-term treatment with AR antagonists. ${ }^{3}$ The mutation in AR is considered a possible reason for rendering prostate cancer cells hormone refractory. ${ }^{4}$ Furthermore, anilide-type AR antagonists act as agonists toward hormone-refractory prostate cancer cells in some cases. ${ }^{5-7}$ Thus, development of a new type of AR antagonist is an attractive strategy to overcome prostate cancers that are resistant to the known $A R$ antagonists.

In the course of screening for a new type of AR antagonist, we isolated a novel compound, arabilin, with two known structural isomers, spectinabilin and SNF4435C, from Streptomyces sp. MK756-CF1. In this paper, the isolation, structure elucidation and biological activities of arabilin are reported.

\section{RESULTS AND DISCUSSION}

Screening for binding inhibitors of DHT and AR

To obtain a new type of AR antagonist with a nonsteroidal/nonanilidetype structure, we first screened more than 2000 microbial extracts to find inhibitors, which could inhibit the binding of dihydrotestosterone (DHT) to AR using a $\left[{ }^{3} \mathrm{H}\right] \mathrm{DHT}-\mathrm{AR}$ in vitro binding assay. In the course of screening, we found that the culture broth extract of strain MK756-CF1 inhibited the binding of DHT to AR.

\section{Taxonomy of the producing strain}

Strain MK756-CF1 produced spore chains on aerial mycelia, which developed from branched substrate mycelia. The partial gene sequence (1412 bp) coding 16S ribosomal RNA of MK756-CF1 showed high homology with those of members of the genus Streptomyces, such as Streptomyces spectabilis (National Institute of Technology and Evaluation Biological Research Center (NBRC) 13423T 1408/1413 bp, 99\%) and Streptomyces flavofungini (NBRC 13371T 1391/1412 bp, 98\%). These phenotypic and genotypic properties suggested that strain MK756-CF1 belonged to the genus Streptomyces. Further detailed taxonomic study of strain MK756-CF1 is in progress.

Isolation of arabilin, spectinabilin and SNF4435C

The cultivation of strain MK756-CF1 was carried out in $60500-\mathrm{ml}$ Erlenmeyer flasks containing pressed wheat $(2.4 \mathrm{~kg})$ because this solidstate fermentation enabled the strain to produce abundant active

\footnotetext{
${ }^{1}$ Department of Biosciences and Informatics, Faculty of Science and Technology, Keio University, Yokohama, Japan and ${ }^{2}$ Institute of Microbial Chemistry, Tokyo, Japan 3These authors contributed equally to this work.

Correspondence: Professor M Imoto, Department of Biosciences and Informatics, Keio University, 3-14-1 Hiyoshi Kohoku-ku, Yokohama, Kanagawa, 223-8522, Japan. E-mail: imoto@bio.keio.ac.jp
}

Received 15 June 2010; revised 15 July 2010; accepted 21 July 2010; published online 25 August 2010 
components. After fermentation, the culture was extracted with EtOH (21), filtrated and concentrated in vacuo. This suspension was adjusted to $\mathrm{pH}$ 7.0, followed by extraction with EtOAc (31) twice, and the organic layer was concentrated to give a pink oily residue $(2.2 \mathrm{~g})$. Thus, the obtained crude active oil was subsequently subjected to silica gel column chromatography (Silica gel 60, 60-230 $\mu \mathrm{m}$; Merck, Darmstadt, Germany) using an $n$-hexane-EtOAc stepwise system. One active fraction ( $n$-hexane-EtOAc, 2:1) was further purified by preparative octadecyl silyl (ODS) HPLC (Sun Fire, $10 \mu \mathrm{m}, 19 \times 250 \mathrm{~mm}$; Waters, Milford, MA, USA) with $80 \%$ aqueous $\mathrm{MeOH}$ to give a pure novel compound, arabilin $(3.3 \mathrm{mg}$ ) (Figure 1). Another active fraction obtained by silica gel column chromatography ( $n$-hexane-EtOAc, $1: 1$ ) was also further purified by preparative ODS HPLC to give spectinabilin $(3.0 \mathrm{mg})^{8}$ and SNF4435C $(6.0 \mathrm{mg})^{9}$ (Figure 1). Spectinabilin and SNF4435C were reported as a weak inhibitor of Rauscher leukemia virus reverse transcriptase ${ }^{8}$ and a potent immunosuppressant, ${ }^{9}$ respectively.

\section{Structure elucidation of arabilin}

The physicochemical properties of arabilin, as well as spectinabilin and SNF4435C, are summarized in Table $1{ }^{8,10}$ From HRESI-MS measurements in combination with ${ }^{1} \mathrm{H}$ and ${ }^{13} \mathrm{C}$ NMR data, the molecular formula of arabilin was determined to be $\mathrm{C}_{28} \mathrm{H}_{31} \mathrm{NO}_{6}$ (found: 478.2215 $[\mathrm{M}+\mathrm{H}]^{+}$, calcd: 478.2224$)$, the same as spectinabilin and SNF4435C. As the ${ }^{1} \mathrm{H}$ and ${ }^{13} \mathrm{C}$ NMR spectra of arabilin were partially similar to those of spectinabilin, 8,11 a structural study of arabilin was performed by comparing with spectinabilin. The IR spectrum revealed that arabilin possesses a ketone conjugated with a double bond $\left(1666 \mathrm{~cm}^{-1}\right)$ and a nitro group (1516 and $\left.1342 \mathrm{~cm}^{-1}\right)$, as does spectinabilin. On the other hand, the UV spectrum of arabilin $\left(\lambda_{\text {max }}: 263 \mathrm{~nm}(\varepsilon 18400), 315 \mathrm{~nm}(\mathrm{sh}, \varepsilon 10300)\right)$ was different from that of spectinabilin ( $\lambda_{\max }: 252 \mathrm{~nm}(\varepsilon 17600), 268 \mathrm{~nm}(\varepsilon 18200)$, $367 \mathrm{~nm}(\varepsilon 15500)) .{ }^{8}$ The structure of arabilin was mainly determined by NMR spectral analyses as follows. We established direct connectivity

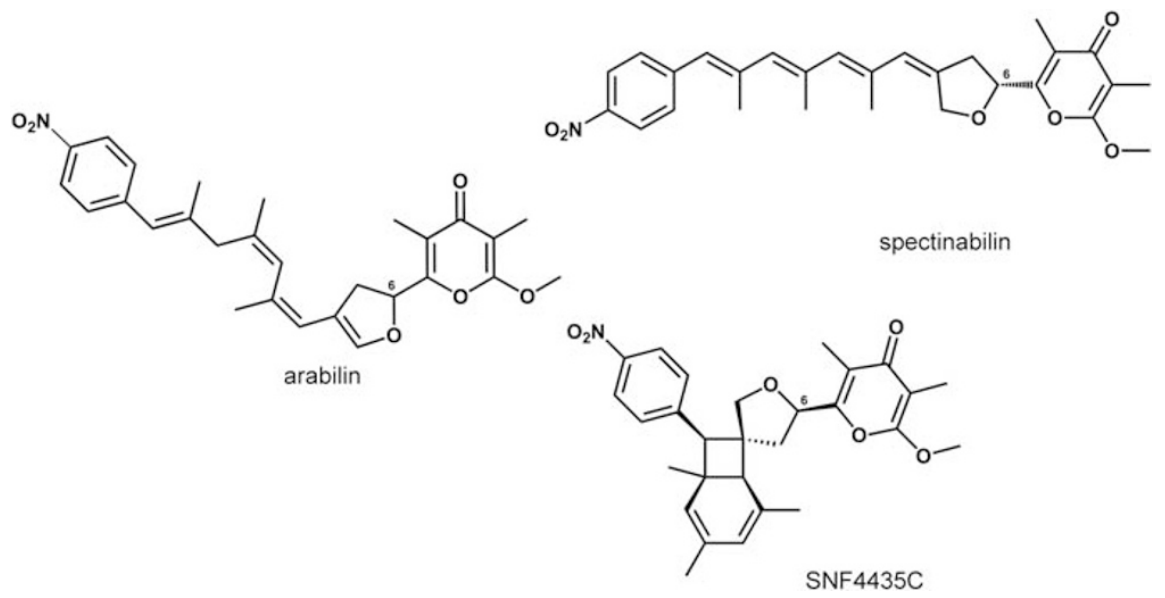

Figure 1 Structures of arabilin, spectinabilin and SNF4435C.

Table 1 Physicochemical properties of arabilin, spectinabilin and SNF4435C

\begin{tabular}{|c|c|c|c|}
\hline & Arabilin & Spectinabilin & SNF4435C \\
\hline Molecular formula & $\mathrm{C}_{28} \mathrm{H}_{31} \mathrm{NO}_{6}$ & $\mathrm{C}_{28} \mathrm{H}_{31} \mathrm{NO}_{6}$ & $\mathrm{C}_{28} \mathrm{H}_{31} \mathrm{NO}_{6}$ \\
\hline \multicolumn{4}{|c|}{ HRESI-MS (m/z, Positive) } \\
\hline Calcd & $478.2224\left(\right.$ as $\mathrm{C}_{28} \mathrm{H}_{32} \mathrm{NO}_{6}$ ) & - & - \\
\hline Found & 478.2215 & - & - \\
\hline IR $V_{\max }\left(\mathrm{cm}^{-1}\right)(\mathrm{KBr})$ & $2956,2854,1666,1597,1516,1342$ & $1670,1520,1340^{\mathrm{a}}$ & $2950,2850,1695,1600,1520,1350^{b}$ \\
\hline UV $\lambda_{\max }(\mathrm{nm})(\varepsilon)$ & 263 (18400), 315 (sh, 10300) (MeOH) & $\begin{array}{l}218(19100), 252(17600), 268(18200) \\
367(15500)(\mathrm{EtOH})^{\mathrm{a}}\end{array}$ & $271(19300)(\mathrm{MeOH})^{\mathrm{b}}$ \\
\hline $\operatorname{TLC}\left(R_{\mathrm{F}}\right)^{\mathrm{C}}$ & 0.68 & 0.51 & 0.55 \\
\hline HPLC $(R t, \min )^{d}$ & $25.2(85 \% \mathrm{MeOH})$ & $23.5(85 \% \mathrm{MeOH})$ & $16.7(85 \% \mathrm{MeOH})$ \\
\hline \multicolumn{4}{|l|}{ Solubility } \\
\hline
\end{tabular}

aKakinuma et al. ${ }^{8}$

bTakahashi K et al 10

'Silica gel TLC (Kieselgel $60 \mathrm{~F}_{254}$; Merck); mobile phase, $n$-hexane-EtOAc (1:2).

${ }^{d}$ Column, SunFire ODS (Waters, $5 \mu \mathrm{m}, 4.6 \times 250 \mathrm{~mm}$ ); mobile phase, aqMeOH; flow rate, $0.7 \mathrm{ml} \mathrm{min}^{-1}$. 
between each proton and carbon by the heteronuclear multiple quantum coherence (HMQC) spectrum; the ${ }^{1} \mathrm{H}$ and ${ }^{13} \mathrm{C}$ spectral data for arabilin are shown in Table 2. The ${ }^{1} \mathrm{H}^{-1} \mathrm{H}$ COSY and Heteronuclear Multiple Bond Coherence (HMBC) spectra proved that arabilin has both a 2 -methoxy-3,5-dimethyl- $\gamma$-pyrone moiety

Table $2{ }^{13} \mathrm{C}$ - and ${ }^{1} \mathrm{H}$-NMR data for arabilin in $\mathrm{CDCl}_{3}$

\begin{tabular}{|c|c|c|}
\hline Number & $\delta c(p . p . m)$. & $\delta_{H}(p . p . m)$. \\
\hline 1 & 162.1 & - \\
\hline $1 \mathrm{a}$ & 55.3 & $3.92(3 \mathrm{H}, \mathrm{s})$ \\
\hline 2 & 99.9 & - \\
\hline $2 a$ & 6.9 & $1.86(3 \mathrm{H}, \mathrm{s})$ \\
\hline 3 & 180.6 & - \\
\hline 4 & 119.6 & - \\
\hline $4 a$ & 9.4 & $2.02(3 \mathrm{H}, \mathrm{s})$ \\
\hline 5 & 154.2 & - \\
\hline 6 & 77.2 & $5.59(1 \mathrm{H}, \mathrm{dd}, J=7.7,11.0)$ \\
\hline 7 & 35.6 & $\begin{array}{l}2.85(1 \mathrm{H}, \mathrm{dd}, J=7.5,15.2) \\
3.08(1 \mathrm{H}, \mathrm{dd}, J=11.0,15.2)\end{array}$ \\
\hline 8 & 114.9 & - \\
\hline $8 a$ & 144.4 & $6.48(1 \mathrm{H}, \mathrm{s})$ \\
\hline 9 & 118.5 & $5.91(1 \mathrm{H}, \mathrm{s})$ \\
\hline 10 & 131.7 & - \\
\hline $10 a$ & 25.3 & $1.88(3 \mathrm{H}, \mathrm{bs})$ \\
\hline 11 & 128.6 & $5.99(1 \mathrm{H}, \mathrm{s})$ \\
\hline 12 & 134.7 & - \\
\hline $12 \mathrm{a}$ & 22.8 & $1.73(3 \mathrm{H}, \mathrm{bd})$ \\
\hline 13 & 44.2 & $2.91(2 \mathrm{H}, \mathrm{s})$ \\
\hline 14 & 141.1 & - \\
\hline $14 a$ & 18.1 & $1.81(3 \mathrm{H}, \mathrm{bd})$ \\
\hline 15 & 124.9 & $6.32(1 \mathrm{H}, \mathrm{s})$ \\
\hline 16 & 145.1 & - \\
\hline 17 & 129.3 & $7.35(2 \mathrm{H}, \mathrm{d}, J=8.8)$ \\
\hline 18 & 123.5 & $8.17(2 \mathrm{H}, \mathrm{d}, J=8.8)$ \\
\hline 19 & 145.9 & - \\
\hline
\end{tabular}

Chemical shifts in p.p.m. from TMS as an internal standard.
(C-1 to C-5) and a p-nitrophenyl group (C-16 to C-19), as does spectinabilin (Figure 2 and Jacobsen et al. ${ }^{11}$ ). This finding and the difference between the UV spectrum of arabilin and that of spectinabilin imply that the tetraene moiety combined with a substituted furan moiety in spectinabilin is not preserved in arabilin. In the ${ }^{1} \mathrm{H}$ NMR spectra, one singlet methylene signal $\left(\delta_{\mathrm{H}} 2.91, \mathrm{H}-13,2 \mathrm{H}\right)$ was observed only in arabilin (Table 2 and Jacobsen et al. ${ }^{11}$ ). In the HMBC spectrum of arabilin, ${ }^{1} \mathrm{H}-{ }^{13} \mathrm{C}$ long-range couplings from two methyl protons $\left(\delta_{\mathrm{H}} 1.73, \mathrm{H}-12 \mathrm{a}\right.$ and $\left.\delta_{\mathrm{H}} 1.81, \mathrm{H}-14 \mathrm{a}\right)$ to an $\mathrm{sp}^{3}$ carbon $\left(\delta_{\mathrm{C}} 44.2\right.$, C-13) were observed (Figure 2 ), whereas no ${ }^{1} \mathrm{H}-{ }^{13} \mathrm{C}$ longrange coupling from the methyl proton to $\mathrm{sp}^{3}$ carbon was observed in that of spectinabilin (data not shown). In addition, ${ }^{1} \mathrm{H}-{ }^{13} \mathrm{C}$ long-range couplings from a methine proton $\left(\delta_{\mathrm{H}} 6.48, \mathrm{H}-8 \mathrm{a}\right)$ to a methine carbon bearing oxygen $\left(\delta_{\mathrm{C}} 77.2, \mathrm{C}-6\right)$, a methylene carbon $\left(\delta_{\mathrm{C}} 35.6, \mathrm{C}-7\right)$ and a quaternary $\mathrm{sp}^{2}$ carbon $\left(\delta_{\mathrm{C}} 114.9, \mathrm{C}-8\right)$ indicated that $\mathrm{C}-8$ and $\mathrm{C}-8 \mathrm{a}$ are connected by a double bond in arabilin but not in spectinabilin. Thus, the partial structures of arabilin other than a substituted $\gamma$-pyrone ring and a $p$-nitrophenyl group (C-5 to $\mathrm{C}$-16) were also determined on the basis of ${ }^{1} \mathrm{H}-{ }^{1} \mathrm{H}$ COSY and $\mathrm{HMBC}$ analyses (Figure 2). The geometries of C-8/C-8a, C-9/C-10, C-11/C-12 and C-14/C-15 were determined to be $E, Z, Z$ and $E$ by NOE observation between $\mathrm{H}-8 \mathrm{a}\left(\delta_{\mathrm{H}} 6.48\right)$ and $\mathrm{H}-9\left(\delta_{\mathrm{H}} 5.91\right), \mathrm{H}-9$ and $\mathrm{H}-10 \mathrm{a}\left(\delta_{\mathrm{H}} 1.88\right)$, $\mathrm{H}-11\left(\delta_{\mathrm{H}} 5.99\right)$ and $\mathrm{H}-12 \mathrm{a}\left(\delta_{\mathrm{H}} 1.73\right)$, and $\mathrm{H}-13\left(\delta_{\mathrm{H}} 2.91\right)$ and $\mathrm{H}-15$ $\left(\delta_{\mathrm{H}} 6.32\right)$, respectively (Figure 2$)$. From the above findings, the planar structure of arabilin was determined as shown in Figure 1. Thus, it was revealed that all arabilin and its structural isomers, spectinabilin and SNF4435C, had a $p$-nitrophenyl group and a substituted $\gamma$-pyrone ring. The configurations at C-6 in spectinabilin, its analog aureothin and SNF4435C were determined as $R . .^{12,13}$ The stereochemistry of arabilin has not yet been determined and is now under study.

\section{Effects of arabilin, spectinabilin and SNF4435C on binding of DHT to AR}

Arabilin, spectinabilin and SNF4435C inhibited the binding of DHT to $\mathrm{AR}$ in a dose-dependent manner (Figure 3). The $\mathrm{IC}_{50}$ values of arabilin, spectinabilin and SNF4435C were $11 \mu \mathrm{M}, 13 \mu \mathrm{M}$ and $7 \mu \mathrm{M}$, respectively, and these inhibitory activities were about 10 -fold more
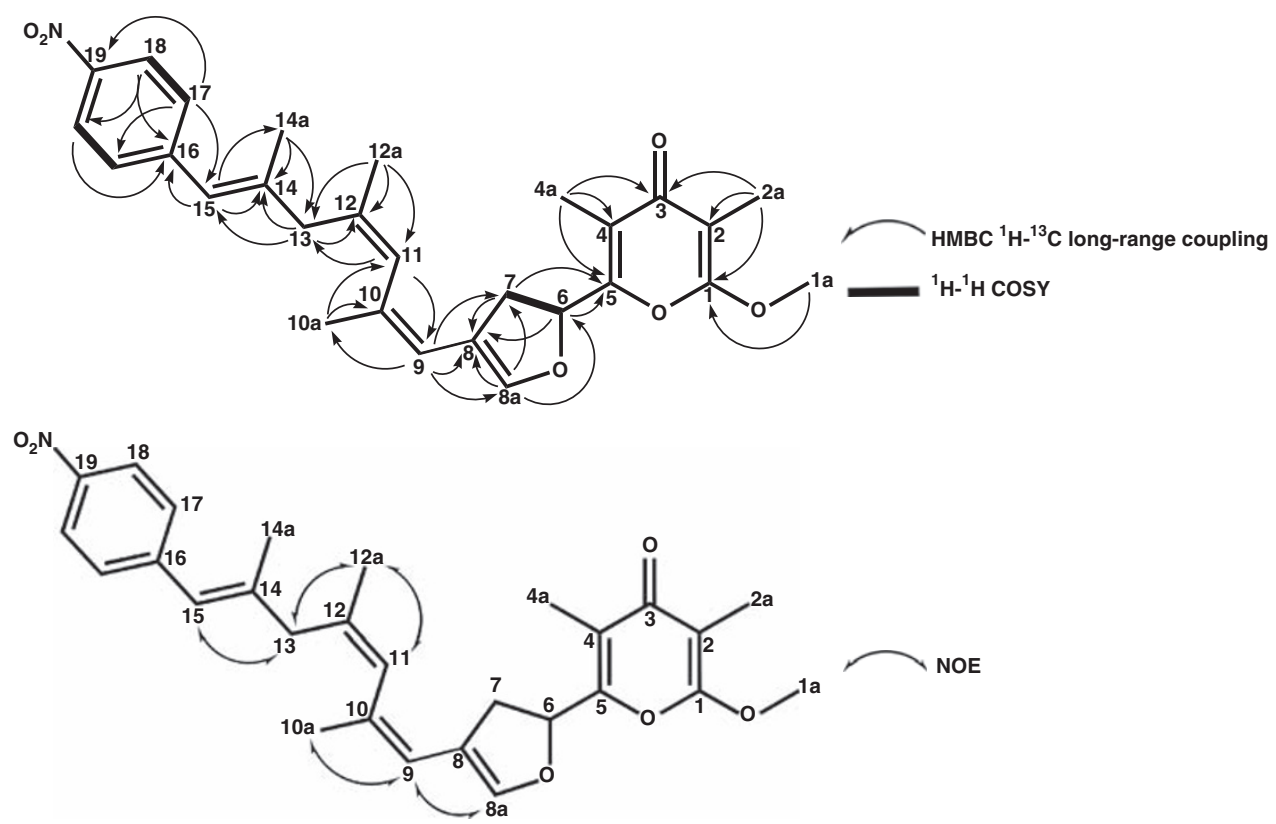

Figure 2 Structures of arabilin elucidated by ${ }^{1} \mathrm{H}_{-}{ }^{1} \mathrm{H}$ COSY, NOE and heteronuclear multiple bond coherence (HMBC) experiments. 
potent than that of flutamide, which was clinically used for the treatment for prostatic diseases. On the other hand, arabilin, spectinabilin and SNF4435C did not show inhibitory activity against binding of estradiol to estrogen receptor up to $100 \mu \mathrm{M}$ (data not shown).

\section{Effects of arabilin, spectinabilin and SNF4435C on DHT-induced PSA expression}

Prostate-specific antigen (PSA) is a $33-\mathrm{kDa}$ serine protease, whose expression in the prostate is triggered by androgen-mediated action of AR; therefore, to determine whether arabilin, spectinabilin and

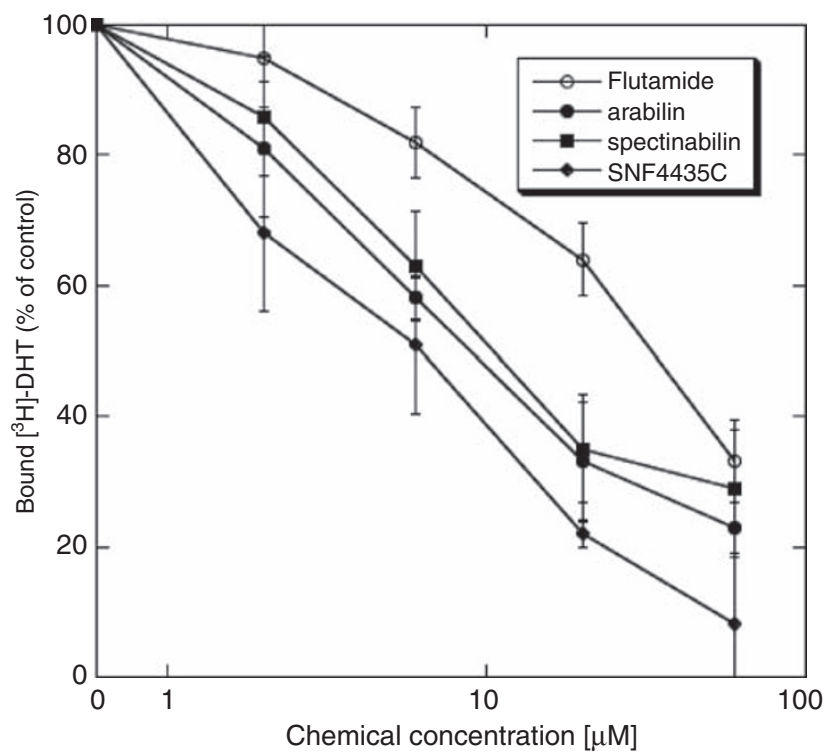

Figure 3 Effects of arabilin, spectinabilin, SNF4435C and flutamide on binding of dihydrotestosterone (DHT) to androgen receptor (AR). A $50 \mu \mathrm{g} \mathrm{ml}^{-1}$ volume of maltose-binding protein-AR-ligand-binding domain (MBP-ARLBD), $2 \mathrm{~nm}\left[{ }^{3} \mathrm{H}\right] \mathrm{DHT}$ and the indicated concentrations of test compounds were incubated at $4^{\circ} \mathrm{C}$ for $3 \mathrm{~h}$. Then, the radioactivity of $\left[{ }^{3} \mathrm{H}\right] \mathrm{DHT}$ bound to MBP-AR-LBD was measured with a liquid scintillation counter. Values are the means of four samples; bars, s.d.
SNF4435C showed AR antagonistic activity, we examined the effects of these compounds on DHT-induced expression of PSA mRNA in prostate cancer LNCaP cells. As shown in Figure 4, arabilin, spectinabilin and SNF4435C inhibited the DHT-induced expression of endogenous PSA mRNA in LNCaP cells with $\mathrm{IC}_{50}$ values of $210 \mathrm{nM}$, $1.75 \mathrm{~nm}$ and $274 \mathrm{~nm}$, respectively, whereas they did not induce the expression of PSA mRNA (data not shown). These three compounds did not inhibit DHT-independent GAPDH gene expression under these conditions (data not shown). Spectinabilin was reported to inhibit Ascaris NADH-fumarate reductase, ${ }^{14}$ and we found that it inhibited mitochondrial respiration of tumor cells, but its $\mathrm{IC}_{50}$ value is about $100 \mathrm{~nm}$. Therefore, inhibition of DHT-induced expression of PSA mRNA by these compounds is not due to nonspecific toxic effect or global RNA synthesis-inhibitory effect, but due to AR antagonistic effect. Thus, we obtained a new type of AR antagonists with nonsteroidal/nonanilide-type structures. At present, we do not know why spectinabilin showed 100 -fold potent inhibitory activity against DHTinduced PSA mRNA expression when compared with arabilin and SNF4435C. The precise mechanism for the inhibition of DHT-induced PSA mRNA expression by these compounds is now under investigation. In addition, the antitumor activities of these compounds in androgen-dependent and -independent prostate cancer cell functions will be reported elsewhere.

\section{METHODS}

\section{General experimental procedures}

Mass spectra were measured with JMS-T100LC mass spectrometer (JEOL, Tokyo, Japan). Optical rotations were made with P-1030 polarimeter (JASCO, Tokyo, Japan) using a micro-cell (light path $100 \mathrm{~mm}$ ). UV spectra and IR spectra were recorded on U-1800 spectrophotometer (Hitachi HighTechnologies, Tokyo, Japan) and FT-210 spectrometer (Horiba, Kyoto, Japan) in $\mathrm{KBr}$ disc, respectively. ${ }^{1} \mathrm{H}$ and ${ }^{13} \mathrm{C}$ NMR spectra were recorded on JNM-ECA600 spectrometer (JEOL) operating at $600 \mathrm{MHz}$ and $150 \mathrm{MHz}$, respectively. A liquid chromatography (LC)-photo diode array (PDA)-MS system (Waters) with a photo diode array detector (2996) and mass analyzer (Micromass ZQ; Waters) was used for analysis and preparation.

\section{Taxonomic studies}

The producing strain, MK756-CF1, was isolated from a soil sample collected in Kochi prefecture, Japan. The morphological characteristics of strain
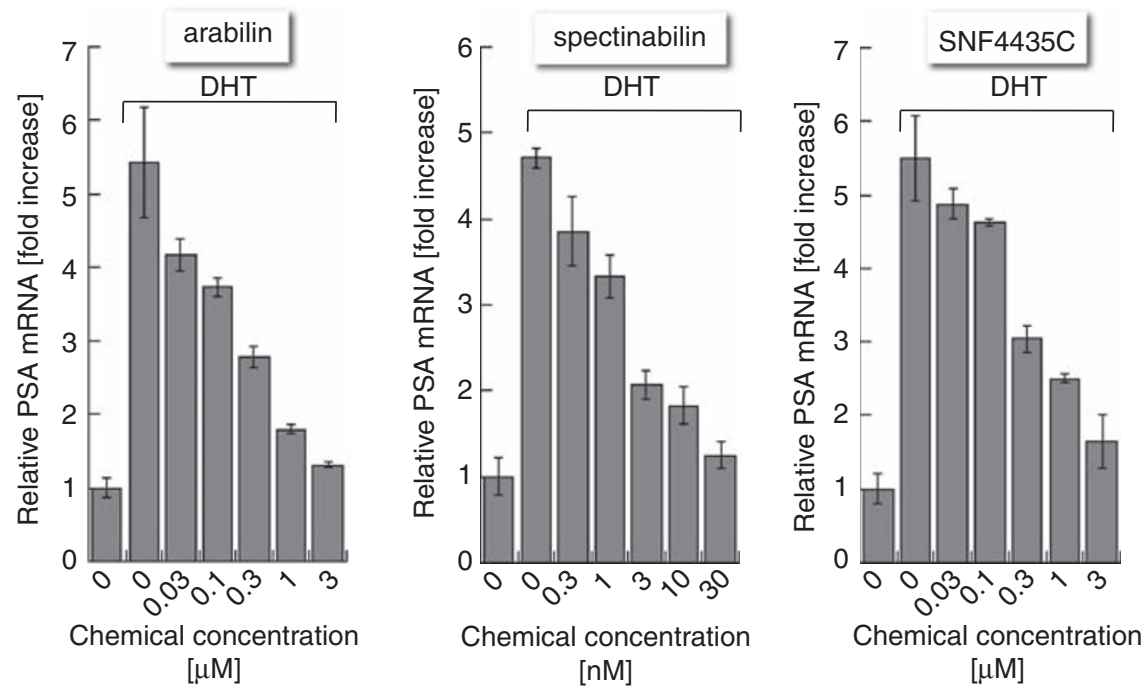

Figure 4 Effects of arabilin, spectinabilin and SNF4435C on dihydrotestosterone (DHT)-induced prostate-specific antigen (PSA) mRNA expression. LNCaP cells were treated with $0.1 \mathrm{~nm}$ of DHT and the indicated concentrations of test compounds. After $12 \mathrm{~h}, \mathrm{PSA}$ mRNA were measured by real-time quantitative reverse transcription PCR. Values are the means of triplicate samples; bars, s.d. 
MK756-CF1 were determined on yeast-starch agar. The $16 \mathrm{~S}$ ribosomal RNA gene was amplified by PCR using genomic DNA of the strain and sequenced. The most related sequences were searched using the BLAST algorithm in the DNA Data Bank of Japan.

\section{Fermentation}

A slant culture of arabilin-producing organism was inoculated in a $500-\mathrm{ml}$ baffled Erlenmeyer flask containing $110 \mathrm{ml}$ of a seed medium consisting of galactose $2 \%$, dextrin 2\%, Bacto-soytone (Difco; BD, Franklin Lakes, NJ, USA) $1.0 \%$, corn steep liquor (Oji Cornstarch, Tokyo, Japan) $0.5 \%,\left(\mathrm{NH}_{4}\right)_{2} \mathrm{SO}_{4} 0.2 \%$ and $\mathrm{CaCO}_{3} 0.2 \%$ in deionized water ( $\mathrm{pH} 7.4$ before sterilization). The culture was incubated on a rotary shaker $\left(180\right.$ r.p.m. ) at $27^{\circ} \mathrm{C}$ for 3 days. The seed culture $(7 \mathrm{ml})$ of the strain was transferred into a $500-\mathrm{ml}$ Erlenmeyer flask containing autoclaved press wheat $(15 \mathrm{~g})$ with deionized water $(25 \mathrm{ml})$. The fermentation was carried out by a solid-state cultivation at $30^{\circ} \mathrm{C}$ for 14 days.

\section{$\left[{ }^{3} \mathrm{H}\right]$ DHT-AR in vitro binding assay}

This assay was performed according to the method described previously. ${ }^{15}$ In brief, the gene sequence corresponding to the ligand-binding domain (ARLBD, 609-919 amino acids) in the C-terminus of AR was expressed in Escherichia coli strain $\mathrm{DH} 5 \alpha$ as a maltose-binding protein-fused protein (MBP-AR-LBD), followed by purification using amylose resin (Bio-Rad Laboratories, Hercules, CA, USA). Thus, the obtained recombinant MBP-ARLBD $\left(50 \mu \mathrm{g} \mathrm{m}^{-1}\right),\left[{ }^{3} \mathrm{H}\right] \mathrm{DHT}(2 \mathrm{nM})$ and test samples were incubated at $4^{\circ} \mathrm{C}$ for $3 \mathrm{~h}$. Then, $\left[{ }^{3} \mathrm{H}\right]$ DHT-bound MBP-AR-LBD was precipitated with hydroxyapatite and radioactivity was measured with a liquid scintillation counter.

\section{Detection of PSA mRNA by real-time reverse transcription PCR}

Prostate cancer (LNCaP) cells were incubated in RPMI 1640 medium supplemented with $2 \%$ charcoal-stripped serum for $24 \mathrm{~h}$. The cells were then treated with DHT (0.1 nM) and test compounds. After $12 \mathrm{~h}$, RNA from the cells was isolated, and the expression of PSA genes was determined by real-time quantitative reverse transcription PCR, and normalized to GAPDH mRNA. The primer sequences used were as follows: for PSA, $5^{\prime}$-AGGTCGGAGTCAAC GGATTT-3' (forward) and 5'-TAGTTGAGGTCAATGAAGGG-3' (reverse); for GAPDH, 5'-GGTCCTCACAGCTGCCCATC-3' (forward) and 5'-CAGCCTGA GGCGTAGCAGGT-3' (reverse)

\section{ACKNOWLEDGEMENTS}

This study was partly supported by grants from the Ministry of Education, Culture, Sports, Science and Technology of Japan.

1 Gao, W. \& Dalton, J. T. Expanding the therapeutic use of androgens via selective androgen receptor modulators (SARMs). Drug Discov. Today 12, 241-248 (2007).

2 Gao, W., Bohl, C. E. \& Dalton, J. T. Chemistry and structural biology of androgen receptor. Chem. Rev. 105, 3352-3370 (2005).

3 Scher, H. I., Steineck, G. \& Kelly, W. K. Hormone-refractory (D3) prostate cancer: refining the concept. Urology 46, 142-148 (1995).

4 Taplin, M. E. et al. Androgen receptor mutations in androgen-independent prostate cancer: Cancer and Leukemia Group B Study 9663. J. Clin. Oncol. 21, 2673-2678 (2003).

5 Steketee, K. et al. Broadened ligand responsiveness of androgen receptor mutants obtained by random amino acid substitution of $\mathrm{H} 874$ and mutation hot spot $\mathrm{T} 877$ in prostate cancer. Int. J. Cancer. 100, 309-317 (2002).

6 Hara, T. et al. Novel mutations of androgen receptor: a possible mechanism of bicalutamide withdrawal syndrome. Cancer Res. 63, 149-153 (2003).

7 Yoshida, T. et al. Antiandrogen bicalutamide promotes tumor growth in a novel androgen-dependent prostate cancer xenograft model derived from a bicalutamidetreated patient. Cancer Res. 65, 9611-9616 (2005).

8 Kakinuma, K., Hanson, C. A. \& Rinehart, K. L. Jr. Spectinabilin, a new nitro-containing metabolite isolated from Streptomyces spectabilis. Tetrahedron 32, 217-222 (1976).

9 Kurosawa, K., Takahashi, K. \& Tsuda, E. SNF4435C and D, novel immunosuppressants produced by a strain of Streptomyces spectabilis. I. Taxonomy, fermentation, isolation and biological activities. J. Antibiot. 54, 541-547 (2001).

10 Takahashi, K., Tsuda, E. \& Kurosawa, K. SNF4435C and D, novel immunosuppressants produced by a strain of Streptomyces spectabilis. II. Structure elucidation. J. Antibiot. 54, 548-553 (2001)

11 Jacobsen, M. F., Moses, J. E., Adlington, R. M. \& Baldwin, J. E. The total synthesis of spectinabilin and its biomimetic conversion to SNF4435C and SNF4435D. Org. Lett. 7, 2473-2476 (2005)

12 Ishibashi, Y., Nishiyama, S., Shizuri, Y. \& Yamamura, S. Total synthesis of (+)isoaureothin: determination of the absolute configurations of aureothin, isoaureothin and spectinabilin. Tetrahedron Lett. 33, 521-524 (1992).

13 Parker, K. A. \& Lim, Y. H. 'Endo' and 'exo' bicyclo[4.2.0]-octadiene isomers from the electrocyclization of fully substituted tetraene models for SNF $4435 \mathrm{C}$ and D. control of stereochemistry by choice of a functionalized substituent. Org. Lett. 6, 161-164 (2004).

$14 \mathrm{Ui}, \mathrm{H}$. et al. Verticipyrone, a new NADH-fumarate reductase inhibitor, produced by Verticillium sp. FKI-1083. J. Antibiot. 59, 785-790 (2006).

15 Nagamine, N. et al. Integrating statistical predictions and experimental verifications for enhancing protein-chemical interaction predictions in virtual screening. PLoS Comput. Biol. 5, e1000397 (2009). 